Романські мови

Roman languages

СЕМАНТИКО-СИНТАКСИЧНІ ОСОБЛИВОСТІ

ФУНКЩОНУВАННЯ БЕЗОСОБОВИХ КОНСТРУКЩЙ

ІЗ ЗАЙМЕННИКАМИ IL I ÇA У ФРАНЦУЗЬКІЙ МОВІ

Валентина НІЧИЙ

Чернівецький національний університет

імені Юрія Федьковича Чернівці (Україна)

v.nichyi@chnu.edu.ua

\title{
SEMANTIC-SYNTACTIC FEATURES OF THE \\ FUNCTIONING OF IMPERSONAL CONSTRUCTIONS \\ WITH PRONOUNS IL AND CA IN FRENCH
}

Valentyna NICHYI

Yuriy Fedkovych ChernivtsivNational University, Chernivtsi (Ukraine)

ORCID ID: 0000-0002-3945-3766 Researcher ID: N-2288-2017

Ничий В. Семантико-синтаксические особенности функционирования безличных конструкций с местоимениями il и ça во французском языке. Цель исследования. Статья посвящена анализу употребления безличных конструкций с местоимениями $i l$ и с̧а во французском языке. Рассматривается разница их употребления, а также их общие характеристики. Употребление местоимений il и ça рассматривается на примере произведений по художественной литературе, а также научных трудов по лингвистике и точным наукам. Спецификой темы обусловлен комплексный подход к применению методов исследования, среди которых: дескриптивной-эмпирический метод позволил установить формальные, генетические, семантические и функциональные характеристики местоимений, в частности разницу в употреблении местоимений cela и ça. С помощью метода сравнительно-исторического анализа установлено происхождение этих местоименных единиц. Методы функционального и контекстного анализа применены для определения составляющих семантической структуры безличных местоимений, их прагматического потенциала и их актуализации в речи. Статистический метод позволил провести корреляционный анализ употребления безличных конструкций в разножанровых произведениях. Научная новизна. Впервые рассматривается употребление безличных конструкций в художественной и научной литературе и подсчитывается их частотность. Высказана гипотеза о двусмысленности термина "лицо". Выводы. Доказано, что существенное различие в частоте употребления безличных конструкций с местоимениями-подлежащими $i l$ и ça в исследуемых стилях обусловлено характером соответствующих стилей, сферой их применения, объемом используемых слов и конструкций.

Ключевые слова: безличные конструкиии, местоимения il u çа, частота употребления, художественная

Постановка проблеми та їі зв'язок із важливими науковими завданнями. Проблема існування безособових речень в системі різних мов давно $є$ предметом дискусії лінгвокогнітологів, лінгвокультурологів та синтаксистів. Деякі лінгвісти причиною цього існування вважають екстралінгвістичні фактори: специфіку культурних традицій, фаталізм, страх перед невідомим, особливість менталітету певного народу. Іноді вважають, що безособові дієслова беруть свій початок від одноактантних дієслів давніх мов, в сучасних мовах цей єдиний актант прихований. У латинській мові існували дієслова, які вживали тільки в 3-й особі однини різних часів і способів. Такі дієслова називали безособовими (verba impersonalia). Саме від них беруть свій початок безособові конструкції у французькій мові. У французькій мові безпідметові конструкції визначаються за двома характеристиками стосовно структурної позиції підмета: 1) наявністю синтаксичного підмета, позбавленого будь-якого змісту; 2) позицію підмета займає морфема $i l$. На сьогодні немає чіткого розмежування у вживанні займенників il i ça у безособових конструкціях.

Аналіз останніх досліджень і публікацій, у яких започатковано розв'язання проблеми. Деякі лінгвісти стверджують, що il є ознакою безособових конструкцій у французькій мові (див. О. Богомолова, Н. Бозе, Ж.-Кл. Шевальє, Ж. Дюбуа, Р. Лаган, Г. Галіше, М. Іревіс та ін.). Форма с̧а вимагає також уважного вивчення. Підме- ти il i ça вживають у сполученні з метеорологічними дієсловами: поруч з Il pleut, Il neige, Il grêle фіксуємо Ça pleut, Ça neige, Ça grêle, і навіть поруч з Ça flotte чи Ça vase, Il flotte i Il vase. Одночасно існують також дієслова, які сполучаються тільки 3 підметом с̧а, наприклад: с̧а barde, ça balance. Хоча є низка дієслів, які вживаються тільки з підметом il: falloir, pleuvoir, деякі конструкції із дієсловом faire для опису погоди, наприклад: faire beau, faire froid та ін. Досить природно вбачати конкуренцію у вживанні займенників $i l$ та ça. До того ж, вважають, що ça уживають тільки в розмовній мові (Ф. Брюно, Ф. Корблен, П. Кадьйо, М. Маяр та ін.).

Метою написання даної статті $є$ розглянути семантико-синтаксичні особливості функціонування безособових конструкцій із займенниками $i l$ і ça, показати різницю у їх вживанні та навести спільні характеристики їх використання

Виклад основного матеріалу дослідження. Вивчаючи функціонування нейтральних вказівних займенників cela і ça, більшість дослідників розглядає їх як варіанти однієї граматичної форми, абсолютно паралельні у вживанні, які розрізняються лише своєю стильовою відповідністю: cela - у літературній мові, çа - в розмовній. "Quelle que soit son origine, ça s'emploie dans la langue parlée avec les fonctions de cela",

Але комутація між cela i ça не завжди можлива. Це помітив ще Ш. Брюно, який вважав, що займенники cela i ça слід вивчати окремо, оскільки ці займенники не $\epsilon$

\footnotetext{
${ }^{1}$ Bruneau Ch. Questions de grammaire française et de stylistique [Questions of French grammar and stylistics], Paris, 1935 - 1936. P. 197
} 
взаємозамінними. Якщо розмовна мова допускає с̧а pleut, то в літературній cela pleut не можливе. Один 3 найяскравіших прикладів функціональної незалежності ça від cela - вживання займенника с̧а в деяких безособових конструкціях. Зазвичай у французькій мові безособові конструкції визначаються як безпідметні або підметні конструкції 3 дієсловом у 3-ій особі, яке означає дію (стан), реальний виконавець якої або зовсім не виражений, або представлений непрямим додатком чи післядієслівним членом, які і $є$ реальними суб'єктами безособових речень.

Зважаючи на те, що для французької мови характерна тенденція до синтаксичної двоскладності речення, безособові конструкції найчастіше оформляються за допомогою займенника $\mathrm{il}$.

Оскільки позиції $i l$ безособового послаблені внаслідок конкуренції $i l$ - особового займенника чоловічого роду, який в поєднанні з неперехідним дієсловом служить засобом оформлення особових речень, більшість конструкцій 3 займенником il поза макроконтекстом сприймаються і як особові, і як безособові, що призводить до двозначності висловлювання. У літературній мові на рівні широкого контексту така двозначність втрачається, але розмовна мова, яка тяжіє до максимальної ясності і економії засобів вираження, прагне замінити il безособове займенником ça. Вибір саме цієї форми зумовлюється більшою семантичною невизначеністю с̧а порівняно із ceci i cela. Заміна безособового займенника il усіченою формою ça в конструкціях із власне безособовими дієсловами, які позначають атмосфернометеорологічні явища, не зумовлена функціональною необхідністю і тому дуже рідко трапляється в мові персонажів художніх творів. Але конструкції цієї групи, які будують за допомогою неперехідних дієслів і які здатні позначати атмосферно-метеорологічні явища, широко використовують усічену форму с̧а у функції формального підмета. Пояснюється це тим, що поєднання il з неперехідними дієсловами певної семантики неоднозначне i може сприйматися як особове речення. Дієслова geler, dégeler, souffler, tonner можуть оформляти безособові конструкції як 3 il безособовим, так і $з$ ça. Обидва займенника інколи вживають в одному реченні, щоб уникнути повтору: “Au-dehors, ça souffle, mais il ne pleut pas".

Семантичне поле дієслів, які служать для назви атмосферно-метеорологічних явищ, постійно збагачується і розширюється за рахунок нових лексичних одиниць, і для утворення нових безособових конструкцій використовують займенник с̧а.

Деякі 3 них можуть представляти стилістичні i стильові варіанти вже наявних безособових конструкцій. Наприклад: “Dessus ça coulait Nom de Dieu ... Le moteur il était mouillé...”. Синонімічні структури ça dégringole, ça chiale, ça coule замість il pleut, ça tombe замість il neige одночасно несуть стилістичне навантаження, тобто $є$ експресивно забарвленими, характерними для розмовної мови. Інші конструкції, стилістично більш нейтральні, не мають відповідних синонімічних конструкцій 3 il безособовим у літературній мові: ça pique, ça chauffe, ça pince, ça tape, ça glisse та ін.

Уживання цих конструкцій не обмежується сфе- рою розмовної мови, а поширюється й на літературну, що пояснюють неможливістю побудови подібних структур 3 il безособовим або cela: "Il ne fait pas chaud, ça pique!"; "Il a répété en montrant le ciel: "Ça tape”. Дуже продуктивним є використання с̧а як підмета безособових конструкцій з дієсловом faire в поєднанні 3 прикметниками чи іменниками. Ці конструкції позначають стан, умову протікання дії.

С̧a у функції підмета безособових конструкцій може мати референтом усю ситуацію у найширшому розумінні і виражати узагальнене значення: “Tu crois qu'on parleras de nous plus tard? Oh! Ça je m'en fiche bien!.. Ce que je veux, c'est que ça continue comme ça ... toute la vie!...".

Усічена форма с̧а бере участь у творенні речень, які виражають різні процеси, джерело яких невідоме: "La nuit dernière, ça brûlait de partout vers le bas pays".

Різноманітні предикати, 3 якими займенник с̧а структурує, позначають стан стосунків між людьми: "Avec tes copains ça s'arrangera".

Сучасний французький мовознавець М. Маяр називає "безособовими" підмети, які не можуть бути виокремлені зворотом "c'est ... qui" . Якщо заглибитись у тлумачення, притаманне цьому звороту, здається, відмічає автор, що ця конструкція містить в собі групу підметів, які не можуть протиставлятися чомусь іншому.

До цих безособових підметів належать $\mathrm{il}$, деякі випадки вживання ça і on, заперечні називні групи (aucun homme, nul homme, pas un homme). Можна вважати, що згадані безособові підмети не можуть бути протиставлені іншим через дві причини: або через те, що вони не мають точного референтного змісту, або їх референтний зміст виражений дуже нечітко, щоб протиставити іншо$\mathrm{My}^{2}$.

Щодо виразів faire froid i faire chaud, то є випадки, коли доцільніше вживати підмет il: Il fait froid / chaud aujourd'hui.

Il faisait froid. C'était la fin de février.

Проте наявні також випадки, де, на думку французького вченого Ф.Корблена, краще вжити с̧а:

Ça fait froid dans le dos / Ça fait chaud au coeur.

У французькій мові існує низка вживання невираженого підмета с̧а з дієсловами, при яких у функції підмета виступає зазвичай конкретний виконавець дії. Це відбувається в основному у тих випадках, коли мова йде про природні явища: soleil) $)^{3}$

Ça souffle (le vent). Ça plombe. Ça cogne. Ça tape (le

Такі конструкції не мають безособових відповідників:

\section{Il souffle. Il plombe. Il cogne. Il tape .}

Існує чимало випадків, де с̧а не можна замінити ні класичним підметом, ні безособовим il. Це риса таких дієслів, як: barder, chauffer, braiser, saigner та ін. Тут підметом може бути тільки с̧а. Ці конструкції позначають навколишнє середовище. Можна сказати тільки: с̧а balance, ça craint, ça chauffe, ça saigne і т. ін. Визначальною характеристикою сучасної французької мови $\epsilon$ те, що займенник-підмет $i l$ не є єдиним для надання реченню анафоричного змісту. С̧а може також виступати у цій функції. Вважають, що с̧а не можна вважати безосо-

\footnotetext{
${ }^{2}$ Maillard M. "Vers une théorie unitaire de l'impersonnel?" [Towards a unitary theory of the impersonal?], L'impersonnel. Mécanismes linguistiques et fonctionnements littéraire, Grenoble : Ceditel. Université de Grenoble - Stendhal, 1991, P. 232

${ }^{3}$ Corblin F." Sujet impersonnel et sujet indistinct : il et ça" [Impersonal subject and indistinct subject: il and ça], L'impersonnel. Mécanismes linguistiques et fonctionnements littéraires, Grenoble : Ceditel. Université de Grenoble-Stendhal, 1991, P. 143
} 
бовим підметом, а феноменом, властивим деяким безособовим конструкціям (див. детально: Ф.Корблен, П.Кадьйо). У деяких безособових конструкціях існує чітке розмежування у вживанні підметів $i l$ i ça. Але водночас у багатьох інших випадках спостерігаємо паралельне їх вживання. Вживання безособових займенників $i l$ i ça можна розглянути на прикладі творів 3 художньої літератури, а також наукових праць 3 лінгвістики та 3 точних наук. Дослідивши твори французьких письменників XVII століття Ж.-Б. Мольєра і Ж.-Б. Расіна, XIX століття Ф.-Р. де Шатобріана та Г. де Мопассана, XX століття Ф. Саган та Ж.-М. Г. Ле Клезіо, можна зробити висновок, що серед безособових конструкцій у них усіх домінують конструкції із займенником $i l$. Саган, Клезіо і Шатобріан надавали перевагу конструкції $i l y$, тоді як Мопассан, Мольєр і Расін частіше вживали il faut.

Загальна кількість вживання безособових займенників у художніх творах письменників

\begin{tabular}{ccccccccc} 
& Мольєр & Расін & Мопассан & Шатобріа & Саган & \multicolumn{2}{c}{ Ле Клезь- } & Иагалом \\
Il & 502 & 227 & 700 & 204 & 635 & 1316 & 3584 \\
Ça & 20 & 0 & 165 & 0 & 139 & 274 & 598
\end{tabular}

Щодо безособових конструкцій із займенником с̧а, то, як бачимо, найчастіше вони вживаються у творах Ле Клезіо, Саган і Мопассана, тоді як у вибраних творах Шатобріана та Расіна їх немає взагалі ${ }^{4}$.

3 антропоцентричної точки зору можемо зробити висновок, що у всіх шести письменників безособових речень, які мають відношення до людини більше ніж тих, в яких людина не бере безпосередньої участі, тобто займає позицію спостерігача. У творчості цих письменників переважають безособові речення, які відображають фізичні і психічні стани людини, стихійні непередбачені дії людей. У таких реченнях людина займає позицію суб'єкта, який відчуває дію. Якщо розглянути творчість письменників в плані діахронії, то безособові речення, що мають відношення до людини стають дедалі активнішими і 3 плином століть вони функціонують ширше. Це, очевидно, пояснюється тим, що у їх творах широко вживається жива розмовна мова.

Займенник с̧а має властивість вживатися здебільшого у розмовній мові. Структурна схема $i l+V 3 \operatorname{sing}$ у французькій мові може наповнюватися різноманітним

лексичним змістом, формуючи різні звороти, які служать для передачі модальних модифікаторів синтаксичного концепту модуса. Багатозначність значень висуває на перше місце зворот il faut, який знаходить своє вираження як у модусі так і в диктумі висловлювання. Нерідко він виступає модальним модифікатором висловлювання, а також використовується у стійких словосполученнях різного типу.

У досліджуваних творах вищезгаданих письменників даний зворот найчастіше використовується такими авторами як Ж.-Б. Мольєром, Ж. Расіном та Гі де Мопассаном. Зворотом il faut дані письменники передають неминучість, обов'язковість виконання дії. Цей зворот містить в собі сему необхідності виконання якої-небудь дії.

Зворот il y a передає концепт буття/небуття живого/неживого суб'єкта в просторі або в часі. Він стоїть на першому місці за вживанням у творах таких письменників як Ф. Саган і Ж. М. Г. Ле Клезьйо і зовсім відсутній в аналізованих творах Ж. Расіна.

Таблиия 2

Загальна кількість вживання безособових займенників у фахових текстах

$\begin{array}{ccccc} & \text { лінгвістика } & \text { математика } & \text { фізика } & \text { Загалом } \\ \text { il } & 174 & 132 & 88 & 394 \\ \text { ç } & 0 & 5 & 0 & 5\end{array}$

Із наведених підрахунків можна зробити висновок, що в науковому стилі найуживанішими є безособові конструкції у лінгвістиці. Щодо математики і фізики, то їх уживання майже однакове із незначною перевагою деяких типів конструкцій у математиці. Займенник с̧а взагалі відсутній у розглянутих працях з лінгвістики i фізики. У науковому стилі найуживанішими $\epsilon$ безособові конструкції із займенником-підметом $\mathrm{il}$, причому найчастіше вживається конструкція il est + прикметник. Конструкція il y a частіше вживається у лінгвістиці, ніж у математиці. Щодо il faut, то ця конструкція вживається майже однаково як в лінгвістиці, так і в математиці. Проте у фізиці зворот il y

a вживається рідко. Частіше використовуються конструкції il semble та il faut. Однак у фізиці конструкція il faut вживається рідше, ніж у лінгвістиці та математиці.

Висновки та перспективи подальших досліджень. Істотне розходження у частоті вживання безособових конструкцій із займенниками-підметами $i l$ i çа у досліджуваних стилях зумовлено характером відповідних стилів, сферою їх застосування, обсягом використовуваних слів та конструкцій. Комплексне дослідження вживання безособових конструкцій із займенниками $\mathrm{il}$, ça дозволило нам відобразити цілісну картину трактування сучасного стану теорії безособових речень, висві-

\footnotetext{
${ }^{4}$ Nitchiy V. "L'emploi des constructions impersonnelles dans les oeuvres des styles différents" [The use of impersonal constructions in works of different styles], Buletin ştiinţific, Fascicula filologie, Seria A. Baia Mare: Editura Universitatii de Nord, 1914, Vol. XXIII, P. 89 $-106$
} 
тлити методи, за допомогою яких проводилось дослідження та розглянути особливості функціонування безособових конструкцій у різних стилях французької мови. На основі зроблених досліджень для більшої вірогідності нам вдалося також зробити кореляційний аналіз вживання безособових конструкцій у різножанрових творах. У перспективі планується розглянути семантикосинтаксичні особливості функціонування безособових конструкцій французької мови у публіцистиці.

Nichyi Valentyna. Semantic-syntactic features of the functioning of impersonal constructions with pronouns $i l$ and $c ̧ a$ in French. Aim of investigation. The article is devoted to the analysis of the use of impersonal constructions with the pronouns $i l$ and $c ̧ a$ in French. The difference in their use, as well as their general characteristics, are considered. The use of the pronouns $i l$ and $c ̧ a$ is considered on the example of works on fiction, as well as scientific works on linguistics and exact sciences. The specifics of the theme predisposed application of comprehensive approach to the research methodologies, among which there should be mentioned such as: descriptive-empirical method allowed to establish the formal, genetic, semantic and functional characteristics of pronouns, in particular the difference in the use of pronouns cela and ça. Using the method of comparative historical analysis, the origin of these pronominal units is established. Methods of functional and contextual analysis are used to determine the components of the semantic structure of impersonal pronouns, their pragmatic poten- tial and their actualisation in speech. The statistical method made it possible to carry out a correlation analysis of the use of impersonal structures in different genre works. Scientific novelty. For the first time, the use of impersonal constructions in the fiction and scientific literature is considered and their frequency is calculated. The hypothesis about the ambiguity of the term "person" is put forward.

Нічий Валентина - асистент кафедри сучасних іноземних мов та перекладу факультету історії, політології та міжнародних відносин Чернівецького національного університету імені Юрія Федьковича. В науковому доробку автора 19 надрукованих праць. Коло наукових інтересів: безособові речення, проблеми семантичного синтаксису у франиузькій мові, перекладознавство.

Nichyi Valentyna - Teaching Assistant of the Department of Modern Foreign Languages and Translation of the Faculty of History, Political Science and International Studies of Yuriy Fedkovych Chernivtsi National University. In the scientific heritage of the author - 19 published works. Research interests: Impersonal Sentences, Problems in Semantic Syntax in French, Translation.

Received: 24.10 .2017

Advance Access Published: November, 2017

CV. Nichyi, 2017 